\title{
Konsep Dasar Sistem Informasi Manajemen Dan Implementasi Sistem Informasi Manajemen Di Sekolah
}

\author{
Ginta Vonlihana Putri \\ Fakultas Ilmu Pendidikan, Universitas Negeri Padang \\ email : gintavonlihana16@gmail.com
}

\begin{abstract}
ABSTRAK
Sistem informasi manajemen adalah suatu sistem yang ada didalam suatu organisasi, mendukung fungsi operasi yang bersifat manajerial dengan kegiatan disuatu organisasi untuk dapat menyediakan kepada pihak luar gunanya agar informasi yang diperlukan dapat mengambil keputusan. Sistem informasi manajemen disuatu organisasi dikatakan sebagai suatu sistem yang adanya informasi yang dipergunakan kapan saja dan juga dipergunakan oleh semua ditingkatan organisasi. Sistem ini mengambil, mengolah, menyimpan dan memgkomunikasikan informasi yang diterima menggunakan sistem informasi atau sistem lainnya. Sistem informasi manajemen ini dikembangkan dengan alasan adanya permasalahan berupa dengan adanya kendala dan perkembangan organisasi. Implementasi sistem informasi manajemen ini agar dapat meningkatkan kualitas pendidikan dan mempermudah pengaksesan data dalam pendidikan.
\end{abstract}

Kata Kunci : Sistem Informasi Manajemen, Pengambilan Keputusan, Organisasi.

\section{A. PENDAHULUAN}

\section{Latar Belakang Masalah}

Di era globalisasi ini, Sistem informasi manajemen semakin dibutuhkan setiap sekolah maupun, khusunya dalam meningkatkan mengenai informasi disekolah maupun di suatu organisasi dan menciptkan kerja sama dengan pihak lainnya. Oganisasi yang telah melakukan otomatisasi pada setiap manajerialnya 
perlu menindaklanjuti dengan membangun Sistem Informasi Manajemen. Sistem informasi menajemen akan membantu sekolah maupun organisasi dalam memproseskan suatu data, mempercepat dan mengolah data, meningkatkan kualitas informasi dan juga mendorong adanya informasi-informasi yang baru.

\section{Rumusan Masalah}

Dengan adanya suatu permasalahan, maka diperlukan solusi agar masalah tersebut dapat diselesaikan. Oleh karena itu kita harus mengetahui apa saja permasalahan yang ada disekolah. Dengan mengetahui adanya permasalahan tersebut kita tahu bagaimana pengimplementasian sistem informasi manajemen disekolah.

\section{Tujuan Penulisan}

Untuk mengetahui pengertian sistem informasi manajemen, tujuan sistem informasi manajemen, manfaat sistem informasi manajemen dan implementasi sistem informasi manajemen di sekolah.

\section{B. PEMBAHASAN}

\section{Rangkaian Artikel}

\subsection{Pengertian Sistem informasi Manajemen}

(Hartono, 2013) Sistem Informasi Manajemen adalah sebuah sistem, yaitu rangkaian terorganisasi dari sejumlah bagian/komponen yang secara bersama-sama berfungsi atau bergerak menghasilkan informasi untuk digunakan dalam manajemen perusahaan.

Menurut Davis (1994) Pengendalian adalah kegiatan mengukur penyimpangan-penyimpangan dari kinerja yang telah direncanakan. Jadi dapat disimpulkan bahwa sistem informasi manajemen utamanya diarahkan untuk mendukung pengambilan keputusan, serta perencanaan dan pengendalian. 
(Sutabri, 2005) Menurut Robert G Murdick dan Joel E Ross Sistem Informasi Manajemen adalah proses komunikasi dimana informasi masukan (input) direkam, disimpan, dan diproses untuk menghasilkan output yang berupa keputusan tentang perencanaan, pengoperasian, dan pengawasan.

Sistem Informasi Manajemen adalah data, prosesnya adalah pengumpulan, penyimpangan dan pengolahan data tersebut, sedangkan keluarnya adalah informasi. Menurut (Hartono, 2013) lingkungan dari sistem manajamen informasi ini ada 2 sebagai berikut :

1. Lingkungan Internal yaitu sesuatu yang berada di luar Sistem Informasi Manajemen, tetapi berada di dalam sekolah. Lingkungan internal sangat penting karena disinilah terjadi proses pemanfaatan informasi.

2. Lingkungan Eksternal yaitu sesuatu yang berada diluar sekolah. Lingkungan eksternal sangat penting bagi sistem informasi manajemen sebab disinilah data dikumpulkan dan di lingkungan eksternal lah perubahan-perubahan berdampak terhadap SIM.

\subsection{Tujuan Sistem Informasi Manajemen}

Informasi digunakan sebagai menghitung suatu produk dan tujuan yang diinginkan dalam manajemen. selanjutnya informasi digunakan sebagai perencanaan, pengevaluasian dalam sistem informasi manajemen. Informasi dalam sistem informasi manajemen juga bisa untuk pengambilan keputusan. Tujuan ini menunjukkan bahwa manajer memiliki akses informasi dan mengetahui bagaimana cara pemakainnya.

Menurut Sutabri (2005) informasi adalah data yang telah di klasifikasi atau diolah untuk digunakan dalam proses pengambilan keputusan. Informasi yang jelas akan akan mudah digunakan oleh guru dalam memenuhi kebutuhan akan informasi yang diperlukan (Agustiandra \& Sabandi, 2019). 
Menurut (Kurniawan, 2013) tujuan dari sistem informasi manajemen adalah untuk memberikan solusi terhadap kegiatan kegiatan yang dilaksanakan disekolah sehingga mempermudah sekolah dalam memanajemen sekolah dan lebih memfokuskan kegiatan dalam peningkatan mutu pendidikan sehingga memberikan hasil pendidikan yang berkualitas.

\subsection{Manfaat Sistem informasi Manajemen}

a) Untuk meningkatkan pengaksesan data secara cepat dan akurat untuk pemakai

b) Untuk mengembangkan proses perencanaan yang efektif dan efesien

c) Meninjau kebutuhan-kebutuhan keterampilan pendukung sistem informasi manajemen

d) Meningkatkan prokduktivitas aplikasi dalam pengembangan sistem.

e) Mempermudah kontrol kehadiran guru dan peserta didik dan memudahkan dalam membuat laporan serta pembuatan administrasi guru

Sistem informasi manajemen merupakan sistem informasi yang mampu menyeimbangkan biaya dan manfaat yang akan diperoleh maksudnya sistem informasi manajemen menghemat biaya dan meningkatkan pendapatan yang muncul dari informasi yang bermanfaat. Organisasi menyadari bahwa mereka cukup realistis, cermat dan menerapkan sistem informasi manajemen agar sesuai dengan keinginan dalam menentukan batas biaya dari titik manfaat yang akan diperoleh, maka sistem informasi manajemen menghasilkan keuntungan dalam bentuk uang. 


\subsection{Implementasi Sistem Informasi Manajemen di sekolah}

Sistem Informasi Manajemen mempermudah siswa maupun guru dalam proses belajar mengajar. Penggunaan Sistem Informasi Manajemen akan membuat kegiatan menjadi lebih efektif dan efisien. Proses penilaian terhadap hasil belajar siswa pun dapat dilakukan oleh guru secara cepat dan akurat.

Implementasi sistem informasi manajemen dilihat dari aktivitas manajemen kesiswaan. Aktivitas akademik merupakan dua aktivitas penting dalam sistem informasi manajemen sebab aktivitas akademik ini pendukung aktivitas akademik berupa teknologi informasi. Maka dari itu implementasi sitem informasi manajemen akdemik berbasis teknologi informasi merupakan strategi pengembangan manajemen sekolah yang perlu mendapatkan prioritas, sehingga mendapatkan nilai tambah bagi sekolah (Oliver, 2017).

\section{Kajian Analitis}

Implementasi sistem informasi manajemen disekolah dilihat dari aspek input, proses dan output dapat menunjang implementasi sistem informasi manajemen sekolah dalam meningkatkan mutu layanan pendidikan di sekolah, baik dalam sumber daya manusia, sarana dan prasarana, maupun dana. Selain itu pengetahuan sumber daya manusia, tujuan dan prioritas sumbe daya manusia, ketersediaan peserta didik, dukungan manajemen sekolah, keberadaan struktur dan jadwal, pelaksanaan isi dan kemampuan pendidik. Semuanya dilakukan untuk pengelolaan data baik peserta didik maupun guru. Sistem informasi manajemen sekolah diantarannya seperti sistem informasi data peserta didik. Suatu sistem adalah suatu jaringan kerja dari prosedur-prosedur yang saling berhubungan, berkumpul bersama dengan melakukan sebuah kegiatan untuk menyelesaikan suatu sasaran tertentu. 


\section{Penutup}

\section{Kesimpulan}

Sistem Informasi Manajemen adalah sebuah sistem, yaitu rangkaian terorganisasi dari sejumlah bagian/komponen yang secara bersama-sama berfungsi atau bergerak menghasilkan informasi untuk digunakan dalam manajemen perusahaan.

Tujuan dari sistem informasi manajemen adalah untuk memberikan solusi terhadap kegiatan kegiatan yang dilaksanakan disekolah sehingga mempermudah sekolah dalam memanajemen sekolah dan lebih memfokuskan kegiatan dalam peningkatan mutu pendidikan sehingga memberikan hasil pendidikan yang berkualitas.

Manfaat sistem informasi manajemen Untuk meningkatkan pengaksesan data secara cepat dan akurat untuk pemakai, Untuk mengembangkan proses perencanaan yang efektif dan efesien, Meninjau kebutuhan-kebutuhan keterampilan pendukung sistem informasi manajemen, Meningkatkan prokduktivitas aplikasi dalam pengembangan sistem, Mempermudah kontrol kehadiran guru dan peserta didik dan memeudahkan dalam membuat laporan serta pembuatan administrasi guru.

Implementasi sistem informasi manajemen di sekolah, sistem informasi manajemen tentunya mempermudah siswa maupun guru dalam proses belajar mengajar. Implementasi sistem informasi manajemen dilihat dari aktivitas manajemen kesiswaan. Aktivitas akademik merupakan dua aktivitas penting dalam sistem informasi manajemen sebab aktivitas akademik ini pendukung aktivitas akademik berupa teknologi informasi.

\section{Saran}

Sistem informasi manajemen di suatu sekolah sangatlah penting, karna dengan adanya sistem informasi manajemen ini mempermudah dalam pengaksesan data disekolah dan pengembangan dalam pendidikan. Jadi dengan 
adanya artikel ini semoga dapat bermanfaat dan lebih mengetahui lagi "Konsep sistem informasi manajemen dan implementasi sistem informasi manajemen disekolah".

\section{REFERENSI}

Agustiandra, V., \& Sabandi, A. (2019). Persepsi Guru Terhadap Penerapan Sistem Informasi Manajemen Akademik Di Sekolah Menengah Kejuruan (Smk) Negeri 3 Padang. Jurnal Bahana Manajemen Pendidikan, 8(I), 1-8. Retrieved from

http://ejournal.unp.ac.id/index.php/bahana/article/view/103704

Hartono, B. (2013). Sistem Informasi Manajemen Berbasis Komputer. Jakarta: PT Rineka Cipta.

Kurniawan, Y. (2013). Model Sistem Informasi Manajemen Sekolah Berbasiskan Notasi Unified Modeling Language. ComTech: Computer, Mathematics and Engineering Applications, 4(2), 1128-1137.

https://doi.org/10.21512/comtech.v4i2.2572

Oliver, J. (2017). Implementasi Sistem Informasi Manajemen Sekolah Dalam Meningkatkan Mutu Layanan Pendidikan Di SMK Negeri Karangpucung Kabupaten Cilacap. Journal Ilmiah Mahasiswa Pascasarjana Administrasi Pendidikan, 5(1), 61-68. https://doi.org/10.1017/CBO9781107415324.004

Sutabri, T. (2005). Sistem Informasi Manajemen. Yogyakarta: ANDI OFFSET. 